\title{
AGENESIS OF THE LUNG
}

BY

\author{
PER WEXELS \\ From the Regional Thoracic Surgical Centre, Shotley Bridge Hospital, \\ Newcastle-upon-Tyne
}

\begin{abstract}
Agenesis of the lung is a rare condition, and although 85 authenticated cases have been recorded in the literature, few of these were diagnosed during life.

With the increasing use of radiographs, more of these cases are coming to be recognized, but the difficulties of diagnosis are still considerable. Thirty-four cases have been tabulated by Hurwitz and Stephens (1937) and 10 by Deweese and Howard (1944). A further 41 have been extracted from the literature and are summarized in a similar way in Table I. Two cases recorded here make up the total to 87 cases.
\end{abstract}

\section{CASE REPORTS}

Case 1.-A boy, 16 months old, was born prematurely ( $7 \frac{1}{2}$ months). Two days after birth he developed jaundice which lasted for five days. Aged two months he developed a wheeze with distressed respirations and a cough. His general condition remained good and he took his feeds well. After one month of wheezing he was taken to hospital, where his mother was told that the child was well. Since then he has had eight identical attacks, each consisting of wheezing with rapid, somewhat distressed breathing and a slight cough, usually dry, but occasionally productive. The attacks may last severai weeks, but the child was never cyanosed. The child's mother had asthma in childhood and during her last pregnancy.

On admission his weight was $26 \frac{1}{2} \mathrm{lb}$. There was no clubbing of the fingers, and no cyanosis. He had a cough with very little sputum. He was a well-nourished, healthylooking child with good teeth and no tonsillar enlargement. There were no lymphatic glands palpable. The respiration rate was 28 . The movements on both sides of the chest were equal, and there was slight flattening of the left chest. There was some dullness over the left chest posteriorly and anteriorly. Auscultation gave poor air entry on the left chest, but it was normal on the right side.

The pulse was 120 and regular. The apex beat was situated in the sixth intercostal space in the anterior axillary line, and the heart sounds, which were normal, could be heard in the back of the left chest. Otherwise no abnormalities were noticed.

Other findings were: blood, E.S.R. $1 \mathrm{~mm}$., Hb $76 \%$, R.B.C. $3.600,000$, W.B.C. 9,000; Wassermann reaction negative; urine, normal. No tubercle bacilli were found in fasting gastric juice.

Radiographs of the chest (Fig. 1) showed a complete opacity of the left chest with herniation of the right lung across the middle line: the mediastinum was deviated to the left. The heart shadow was not defined but lay to the left of the spine. The latter looked remarkably clear. Attention was drawn to the hemivertebra on the left side. just above the first dorsal vertebra, and with this was found associated an accessory rib. There was slight scoliosis in the cervical dorsal region. A barium swallow (Fig. 2) showed displacement of the oesophagus to the left. After the child had been in the hospital for four weeks he developed an attack with wheezing, and had a cough with tracheal secretion; the attack lasted about two weeks. Bronchoscopy showed a rather 
TABLE I

\begin{tabular}{|c|c|c|c|c|c|}
\hline No. & Author & Year & Age & Sex & Symptoms \\
\hline $1-34$ & $\begin{array}{l}\text { Hurwitz and } \\
\text { Stephens }\end{array}$ & $1787-1937$ & & $17 * 13 \dagger$ & \\
\hline 35-44 & $\begin{array}{l}\text { Deweese and } \\
\text { Howard }\end{array}$ & 1936-1944 & & $3 * 6 \dagger$ & \\
\hline 45 & Riviere $\quad$. & 1779 & Young & Man & \\
\hline 46 & Pozze & 1812 & & & \\
\hline 47 & Sömmering .. & 1812 & Child & & \\
\hline 48 & Münchmeyer & 1885 & 2 years & Boy & \\
\hline 49 & Wollmann & 1891 & 24, & & \\
\hline 50 & Smith & 1893 & Stillborn & Boy & \\
\hline 51 & Eicken & 1904 & Adult & Woman & \\
\hline 52 & Oberwarth .. & 1904 & 1 year & Girl & \\
\hline 53 & $\begin{array}{l}\text { Allen and } \\
\text { Affelbach }\end{array}$ & 1925 & Stillborn & Girl & \\
\hline 54 & Bönninger . . & 1927 & 37 years & Man & \\
\hline 55 & Lochow & 1929 & 5 months & & \\
\hline 56 & Bönninger . . & 1931 & 27 years & Man & \\
\hline 57 & $\begin{array}{l}\text { Wehr and } \\
\text { Clemens }\end{array}$ & 1934 & Newborn & Girl & \\
\hline 58 & Reinhoff & 1937 & 52 years & Man & $\begin{array}{l}\text { Pneumonia. Apex beat mid-axillary } \\
\text { line. 5th interspace }\end{array}$ \\
\hline 59 & Reinhoff & 1937 & 4 months & Boy & Cyanosed \\
\hline
\end{tabular}


TABLE I-continyed

\begin{tabular}{|c|c|c|c|c|}
\hline $\begin{array}{l}\text { Trachea and } \\
\text { Bronchus }\end{array}$ & $\begin{array}{l}\text { Absent } \\
\text { Lung }\end{array}$ & $\begin{array}{l}\text { Pulmonary } \\
\text { Vessels }\end{array}$ & Other Defects & $\begin{array}{l}\text { Diagnosed } \\
\text { in Life }\end{array}$ \\
\hline & $\begin{array}{ll}\text { Right } & 12 \\
\text { Left } & 22\end{array}$ & & & 2 \\
\hline & $\begin{array}{ll}\text { Right } & 4 \\
\text { Left } & 6\end{array}$ & & & 6 \\
\hline & Right & & & No \\
\hline & Left & & $\begin{array}{c}\text { Enlarged spleen, short } \\
\text { bowel }\end{array}$ & ," \\
\hline & Right & & & , \\
\hline & & & & Yes \\
\hline Left bronchus present & Left & & & No \\
\hline $\begin{array}{l}\text { Ten tracheal rings only: } \\
\text { trachea fused with } \\
\text { oesophagus }\end{array}$ & Both & $\begin{array}{l}\text { Pulmonary artery } \\
\text { into the aorta. } \\
\text { No pulmonary } \\
\text { veins }\end{array}$ & $\begin{array}{l}\text { Closed foramen epiploica. } \\
\text { Both pleura missing. } \\
\text { Rudimentary a tlas. } \\
\text { Patent foramen ovale }\end{array}$ & , \\
\hline $\begin{array}{l}\text { Small blind ending } \\
\text { pouch on left side of } \\
\text { trachea }\end{array}$ & Left & & & , \\
\hline $\begin{array}{l}\text { Right main stem bron- } \\
\text { chus ended blind } 0.5 \\
\mathrm{~cm} \text {. below the carina }\end{array}$ & Right & & & , \\
\hline Trachea ended blindly & Both & $\begin{array}{l}\text { Pulmonary artery } \\
\text { undivided into } \\
\text { the aorta }\end{array}$ & Patent foramen ovale & , \\
\hline $\begin{array}{l}\text { Right bronchus ended } \\
\text { blind } 12 \mathrm{~cm} \text {. from } \\
\text { carina with two small } \\
\text { sacks }\end{array}$ & Right & & & , \\
\hline No left bronchus & Left & $\begin{array}{l}\text { One pulmonary } \\
\text { artery }\end{array}$ & & , \\
\hline $\begin{array}{l}\text { Right bronchus ended } \\
\text { blind } 4 \mathrm{~cm} \text {. from carina }\end{array}$ & Right & & & , \\
\hline $\begin{array}{l}\text { Stenosis of trachea. No } \\
\text { left bronchus }\end{array}$ & Left & $\begin{array}{l}\text { No left pulmon- } \\
\text { ary vessels }\end{array}$ & $\begin{array}{l}\text { Atresius of larynx ; oeso- } \\
\text { phago-tracheal } \\
\text { Septum defect }\end{array}$ & ," \\
\hline $\begin{array}{l}\text { Small pouch at place of } \\
\text { left bronchus }\end{array}$ & , & $\begin{array}{c}\text { Large right pul- } \\
\text { monary artery; } \\
\text { left pulmonary } \\
\text { vessels absent }\end{array}$ & $\begin{array}{l}\text { Left innominate vein into } \\
\text { right auricle urethral } \\
\text { stricture }\end{array}$ & , \\
\hline No right bronchus & Right & $\begin{array}{l}\text { Right pulmonary } \\
\text { artery missing }\end{array}$ & $\begin{array}{l}\text { Imperforate anus. Patent } \\
\text { foramen ovale. Septum } \\
\text { defect }\end{array}$ & Yes \\
\hline
\end{tabular}


TABLE I-continued

\begin{tabular}{|c|c|c|c|c|c|}
\hline No. & Author & Year & Age & Sex & Symptoms \\
\hline 60 & $\begin{array}{l}\text { Yampolsky and } \\
\text { Fowler }\end{array}$ & 1938 & 2 years & Boy & $\begin{array}{l}\text { Slight cough, dyspnoea. Respiration } \\
\text { rate 50. Bronchopneumonia }\end{array}$ \\
\hline 61 & Bohnholtzer & 1938 & Premature & & \\
\hline 62 & Wasmuth & 1938 & 4 weeks & Boy & $\begin{array}{l}\text { Symmetric chest. Percussion sound } \\
\text { dull right side of chest }\end{array}$ \\
\hline 63 & Wasmuth $\quad \ldots$ & 1938 & 3 months & & \\
\hline 64 & $\begin{array}{l}\text { Jamuni and } \\
\text { Ellis }\end{array}$ & 1938 & Premature & Boy & \\
\hline 65 & $\begin{array}{l}\text { Killingsworth } \\
\text { and Hibbs }\end{array}$ & 1939 & 10 days & Girl & $\begin{array}{l}\text { Cyanosis. Right chest lagging by } \\
\text { I respiration. Dull percussion sound; } \\
\text { no breath sounds right side }\end{array}$ \\
\hline 66 & $\begin{array}{l}\text { Choisser and } \\
\text { Bloedorn }\end{array}$ & 1939 & 43 years & Man & $\begin{array}{l}\text { Dyspnoea. Asthmatic attacks one } \\
\text { I year before admission }\end{array}$ \\
\hline 67 & $\begin{array}{l}\text { Stokes and } \\
\text { Brown }\end{array}$ & 1940 & $12 \frac{*}{3}$, & Girl & $\begin{array}{l}\text { Three times pneumonia; dull percus- } \\
\text { sion sound; no breath sounds left } \\
\text { side. Slight cough and colds for } \\
3 \text { months }\end{array}$ \\
\hline 68 & Selander & 1941 & 6 months & Boy & $\begin{array}{l}\text { Rapid breathing; dull percussion } \\
\text { sound; no breath sounds right } \\
\text { side. Heart in right chest }\end{array}$ \\
\hline 69 & $\begin{array}{l}\text { Valle and } \\
\text { Graham }\end{array}$ & 1944 & 41 years & Woman & Asymmetrical chest ; slight dyspnoea \\
\hline 70 & $\begin{array}{l}\text { Valle and } \\
\text { Graham }\end{array}$ & 1944 & 5, & Boy & Left chest smaller than right \\
\hline 71 & $\begin{array}{c}\text { Ferguson and } \\
\text { Neuhauser }\end{array}$ & 1944 & & Girl & $\begin{array}{l}\text { Cough since } 2 \text { months old, poor } \\
\text { gain in weight }\end{array}$ \\
\hline
\end{tabular}


TABLE I-continued

\begin{tabular}{|c|c|c|c|c|}
\hline $\begin{array}{l}\text { Trachea and } \\
\text { Bronchus }\end{array}$ & $\begin{array}{l}\text { Absent } \\
\text { Lung }\end{array}$ & $\begin{array}{l}\text { Pulmonary } \\
\text { Vessels }\end{array}$ & Other Defects & $\begin{array}{l}\text { Diagnosed } \\
\text { in Life }\end{array}$ \\
\hline $\begin{array}{l}\text { Stricture } 1 \mathrm{~cm} \text {. below } \\
\text { carina of right bron- } \\
\text { chus }\end{array}$ & Right & & $\begin{array}{l}\text { Diaphragm at level of } 3 \text { rd } \\
\text { rib right side }\end{array}$ & No \\
\hline $\begin{array}{l}25 \text { tracheal rings. No } \\
\text { right bronchus }\end{array}$ & , & $\begin{array}{l}\text { Right pulmonary } \\
\text { vessels missing }\end{array}$ & $\begin{array}{l}\text { Atresia of anus and } \\
\text { rectum; atresia urogeni- } \\
\text { talis. Patent ductus ar- } \\
\text { teriosus. Open foramen } \\
\text { ovale. Horseshoe kidney }\end{array}$ & , \\
\hline $\begin{array}{l}22 \text { complete tracheal } \\
\text { rings. Trachealis } \\
\text { muscle absent. No } \\
\text { right bronchus }\end{array}$ & , & $\begin{array}{l}\text { Right pulmonary } \\
\text { vessels absent }\end{array}$ & $\begin{array}{l}\text { Patent ductus arteriosus. } \\
\text { Open foramen ovale }\end{array}$ & , \\
\hline $\begin{array}{l}\text { Small rudimentary right } \\
\text { bronchus. Trachealis } \\
\text { muscle absent }\end{array}$ & , & $\begin{array}{l}\text { Right pulmonary } \\
\text { vessels absent }\end{array}$ & Patent ductus arteriosus & , \\
\hline $\begin{array}{l}\text { Rudimentary left bron- } \\
\text { chus }\end{array}$ & Left & & & , \\
\hline $\begin{array}{l}\text { Trachea narrowed to } \\
3 \text { mm.; no right } \\
\text { bronchus }\end{array}$ & Right & $\begin{array}{l}\text { No right pulmon- } \\
\text { ary vessels }\end{array}$ & $\begin{array}{l}\text { Synostosis 1st, 2nd, 3rd } \\
\text { ribs; large right auricle. } \\
\text { Patent ductus arteriosus. } \\
\text { Pulmonary s te n o sis } \\
\text { Patent foramen ovale; } \\
\text { absent left kidney }\end{array}$ & , \\
\hline $\begin{array}{l}\text { Left bronchus very nar- } \\
\text { row }\end{array}$ & Left & $\begin{array}{l}\text { Left pulmonary } \\
\text { artery } 0.5 \mathrm{~cm} . \\
\text { in diameter. En- } \\
\text { larged right pul- } \\
\text { monary vessels }\end{array}$ & $\begin{array}{l}\text { Malformed left } \\
\text { heart enlaricle } \\
\text { stenosis }\end{array}$ & , \\
\hline \multirow[t]{2}{*}{$\begin{array}{l}\text { Small rudimentary left } \\
\text { bronchus } 0.5 \mathrm{~cm} \text {. long }\end{array}$} & , & & & Yes \\
\hline & Right & & & , \\
\hline $\begin{array}{l}\text { Left bronchus ended } \\
\text { blindly } 2 \mathrm{~cm} \text {. from } \\
\text { carina }\end{array}$ & Left & $\begin{array}{l}\text { No pulmonary } \\
\text { vessels left side }\end{array}$ & & " \\
\hline $\begin{array}{l}\text { Complete block of left } \\
\text { main bronchus } 1 \mathrm{~cm} . \\
\text { from carina }\end{array}$ & , & & $\begin{array}{l}\text { Left scapula smaller than } \\
\text { the right }\end{array}$ & , \\
\hline $\begin{array}{l}\text { Left bronchus } 1 \mathrm{~cm} \text {. } \\
\text { long ended abruptly }\end{array}$ &, & & Absent left hand & " \\
\hline
\end{tabular}


PER WEXELS

TABLE I-continued

\begin{tabular}{|c|c|c|c|c|c|}
\hline No. & Author & Year & Age & Sex & Symptoms \\
\hline 72 & $\begin{array}{l}\text { Ferguson and } \\
\text { Neuhauser }\end{array}$ & 1944 & 4 months & Girl & $\begin{array}{l}\text { Respiratory embarrassment noisy, } \\
\text { rapid, cyanosed on exertion. } \\
\text { Pneumonia }\end{array}$ \\
\hline 73 & $\begin{array}{l}\text { Ferguson and } \\
\text { Neuhauser }\end{array}$ & 1944 & $6 \quad "$ & Boy & Left hemithorax smaller than right \\
\hline 74 & $\begin{array}{l}\text { Ferguson and } \\
\text { Neuhauser }\end{array}$ & 1944 & $4 \quad "$ & Girl & $\begin{array}{l}\text { Rapid respirations; diminished expan- } \\
\text { sion of right chest }\end{array}$ \\
\hline 75 & $\begin{array}{l}\text { Ferguson and } \\
\text { Neuhauser }\end{array}$ & 1944 & 3 years & Boy & $\begin{array}{l}\text { Flatness of left chest; left hemi- } \\
\text { thorax smaller than the right }\end{array}$ \\
\hline 76 & Garter & 1945 & 18, & Man & $\begin{array}{l}\text { Dull percussion sound; diminished } \\
\text { breath sounds left side. Flattening } \\
\text { of left chest }\end{array}$ \\
\hline 77 & Mitchell $\quad .$. & 1946 & 2, & Girl & $\begin{array}{l}\text { Normal healthy child until sudden } \\
\text { death after aspirating peanut }\end{array}$ \\
\hline 78 & Field & 1946 & 1 year & Girl & \\
\hline 79 & Field & 1946 & 10 years & Girl & $\begin{array}{l}\text { Asthmatic bronchitis; flattening of } \\
\text { left chest }\end{array}$ \\
\hline 80 & Field & 1946 & & & Cyanosed. Coughing since birth \\
\hline 81 & Pierson & 1946 & 5 months & Boy & $\begin{array}{l}\text { When cold slight dyspnoea; thorax } \\
\text { symmetrical. Heart-sounds right } \\
\text { chest; dull percussion sounds; } \\
\text { absent breath-sounds right side }\end{array}$ \\
\hline 82 & Bowden & 1947 & $15,$, & Girl & $\begin{array}{l}\text { Thorax symmetrical; shortness of } \\
\text { breath }\end{array}$ \\
\hline 83 & Mollison & 1947 & Stillborn & & \\
\hline 84 & Burger & 1947 & 2 months & Girl & Poorly developed \\
\hline 85 & $\begin{array}{l}\text { Nesbit, Paul, } \\
\text { and Middle- } \\
\text { ton }\end{array}$ & 1947 & 50 years & Woman & $\begin{array}{l}\text { Slight dyspnoea. Thoracic tightness, } \\
\text { weakness }\end{array}$ \\
\hline
\end{tabular}


TABLE I-continued

\begin{tabular}{|c|c|c|c|c|}
\hline $\begin{array}{l}\text { Trachea and } \\
\text { Bronchus }\end{array}$ & $\begin{array}{l}\text { Absent } \\
\text { Lung }\end{array}$ & $\begin{array}{l}\text { Pulmonary } \\
\text { Vessels }\end{array}$ & Other Defects & $\begin{array}{l}\text { Diagnosed } \\
\text { in Life }\end{array}$ \\
\hline $\begin{array}{l}\text { Small bud-like structure } \\
\text { at site of right bron- } \\
\text { chus }\end{array}$ & Right & $\begin{array}{l}\text { No pulmonary } \\
\text { artery. No pul- } \\
\text { monary vein on } \\
\text { right side }\end{array}$ & $\begin{array}{l}\text { Patent ductus arteriosus, } \\
\text { hypoplasia of spleen, kid- } \\
\text { ney, and liver }\end{array}$ & Yes \\
\hline $\begin{array}{l}\text { Left main bronchus } 3 \\
\mathrm{~cm} \text {. long }\end{array}$ & Left & & Deformed left external ear & , , \\
\hline No right main bronchus & Right & & $\begin{array}{l}\text { Multiple congenital anom- } \\
\text { alies of the high dorsal } \\
\text { vertebrae, with hemi- } \\
\text { vertebrae and spina bi- } \\
\text { fida fusion of } 3 \text { rd-6th } \\
\text { rib on right side }\end{array}$ & , \\
\hline No left bronchus & Left & & Hare lip, cleft palate & , , \\
\hline $\begin{array}{l}\text { Left main stem bronchus } \\
1.5 \mathrm{~cm} \text {. long }\end{array}$ & , & & & , , \\
\hline $\begin{array}{l}\text { Right bronchus ended } \\
\text { blindly }\end{array}$ & Right & $\begin{array}{l}\text { Absent right pul- } \\
\text { monary vessels }\end{array}$ & & No \\
\hline $\begin{array}{l}\text { Left bronchus small } \\
\text { blind pouch }\end{array}$ & Left & & $\begin{array}{l}\text { Spina bifida. Talipes } \\
\text { equino varus congenital } \\
\text { ptosis }\end{array}$ & Yes \\
\hline $\begin{array}{l}\text { Small rudimentary left } \\
\text { lung }\end{array}$ & , & & & , \\
\hline $\begin{array}{l}\text { Small rudimentary right } \\
\text { lung }\end{array}$ & Right & & $\begin{array}{l}\text { Intraventricular septal } \\
\text { defect }\end{array}$ & , \\
\hline $\begin{array}{l}\text { No carina or right bron- } \\
\text { chus }\end{array}$ &,, & & & , \\
\hline $\begin{array}{l}\text { Right bronchus only } \\
\text { small hollow bud }\end{array}$ &,, & & & No \\
\hline $\begin{array}{l}\text { At side of carina left and } \\
\text { right bronchus ended } \\
\text { blindly }\end{array}$ & Both & & & , \\
\hline $\begin{array}{l}\text { Rudimentary left bron- } \\
\text { chus }\end{array}$ & Left & $\begin{array}{l}\text { No left pulmon- } \\
\text { ary vessels }\end{array}$ & $\begin{array}{l}\text { Patent ductus arteriosus. } \\
\text { Patent foramen ovale. } \\
\text { Two lobes only right side }\end{array}$ & , \\
\hline $\begin{array}{l}\text { Small rudimentary left } \\
\text { bronchus }\end{array}$ & , & & & Yes \\
\hline
\end{tabular}


Fig. 1.-The radiograph shows aeration of the right chest and the left homogeneously opaque. The developmental anomaly at the base of the cervical spine is demonstrated.

Fig. 2.-A barium swallow demonstrates the mediastinal shift to the left.

Fig. 3.-Bronchogram of the right lung, which shows that this lung extends further into the left chest than was suggested by the routine view, and no trace of a left bronchus is seen.

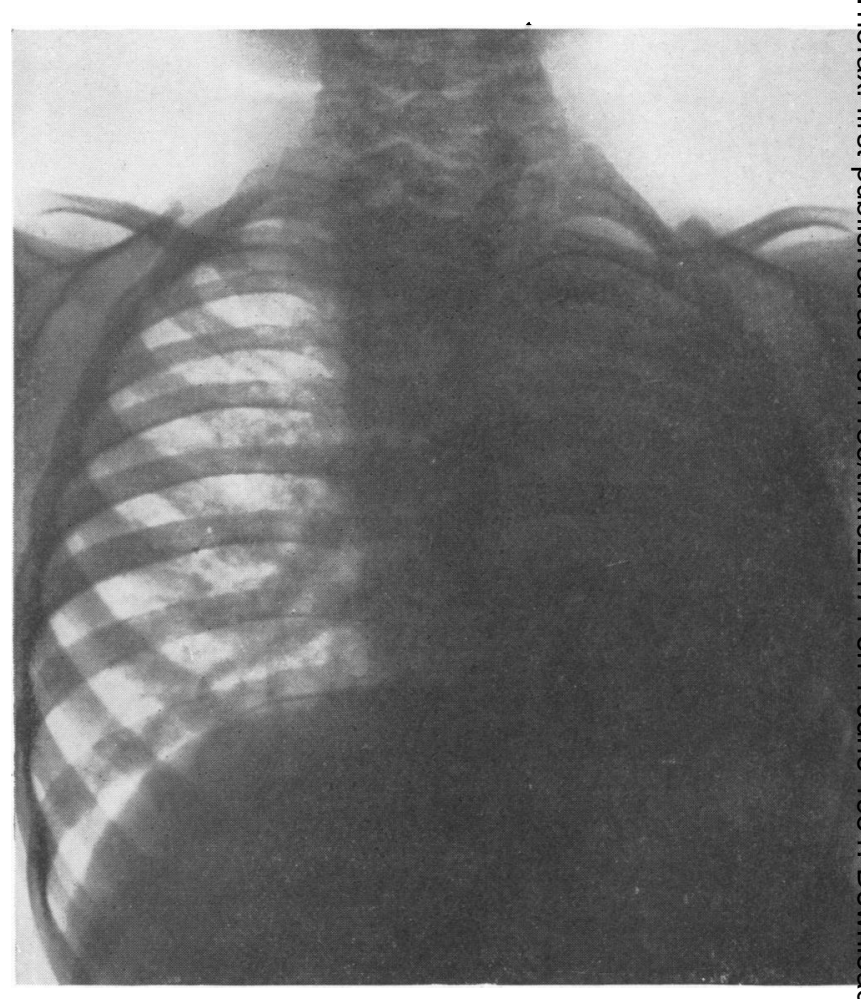

FIG. 1.

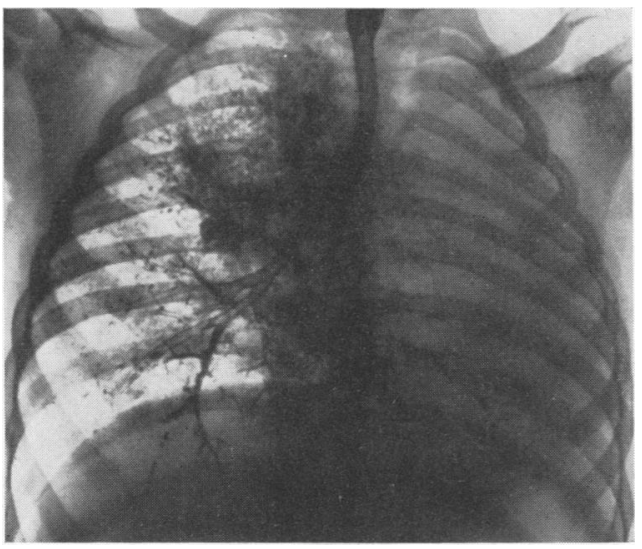

FIG. 3.

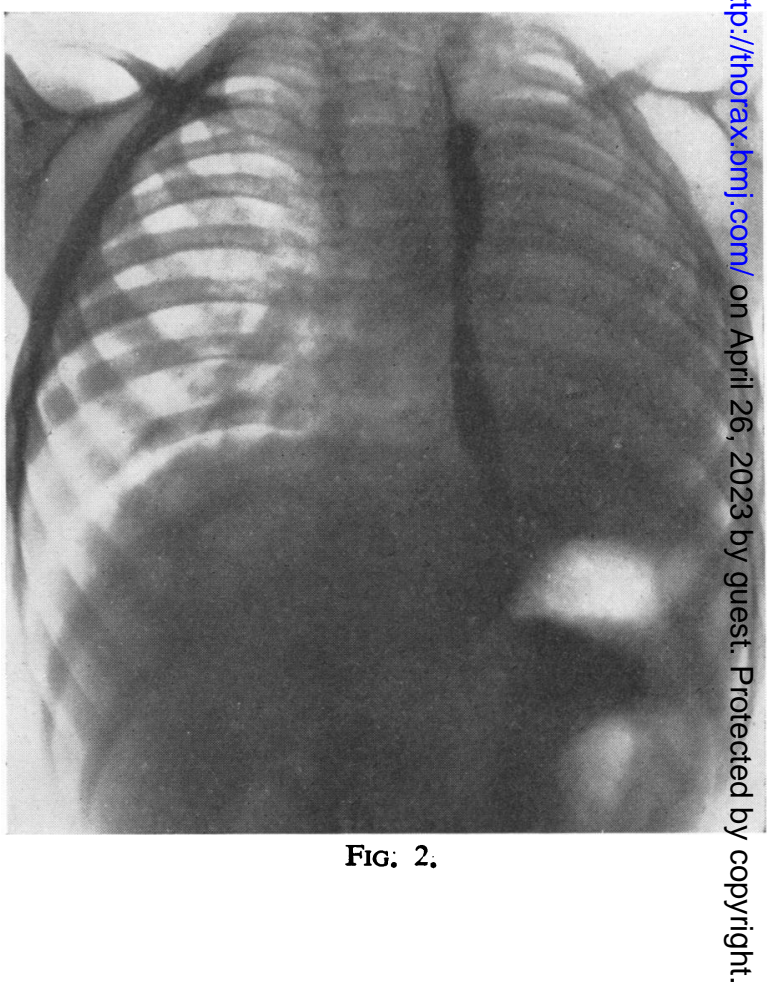


narrow and long trachea dividing into three branches supplying the right lung. No sign of the carina or the left bronchus was seen. A subsequent bronchogram (Fig. 3) showed the absent left bronchus : one branch which might be mistaken for a left bronchus went off below the upper lobe orifice. The right bronchial tree seemed to fill part of the left chest with branches crossing the middle line.

A left thoracotomy was performed. The heart was rotated backwards and upwards to the left. No left lung was found. The mediastinum was explored and a small piece of tissue, which appeared rather like the thymus, was seen lying between the oesophagus and the inferior vena cava. A diagnosis of agenesis of the left lung was made.

The patient had an uncomplicated post-operative course. Figs. $4 a$ and $b$ show a slight flattening of the left chest.

Case 2.-A girl now aged 7 was born at full term after a normal pregnancy. Since about the age of 6 months she had had a cough with a little white mucoid sputum, particularly in the morning and on exposure to cold. There was no history of whoopingcough, pneumonia, or measles.

On admission she weighed 3 st. 8 oz. and was small and thin for her age. There was no cyanosis and no clubbing of the fingers. The respiration rate was 24 per minute. On examination there was slight flattening and lagging on inspiration of the right lateral chest wall (Figs. $5 a$ and $b$ ) at the level of the nipple; the right and left hemithorax both measured $10 \frac{1}{2}$ in. There was dullness on percussion and absent breath sounds over the lower part of the right chest. The apex beat was in the fifth intercostal space in the right anterior axillary line, and there was no cardiac dullness to the left of the sternum.

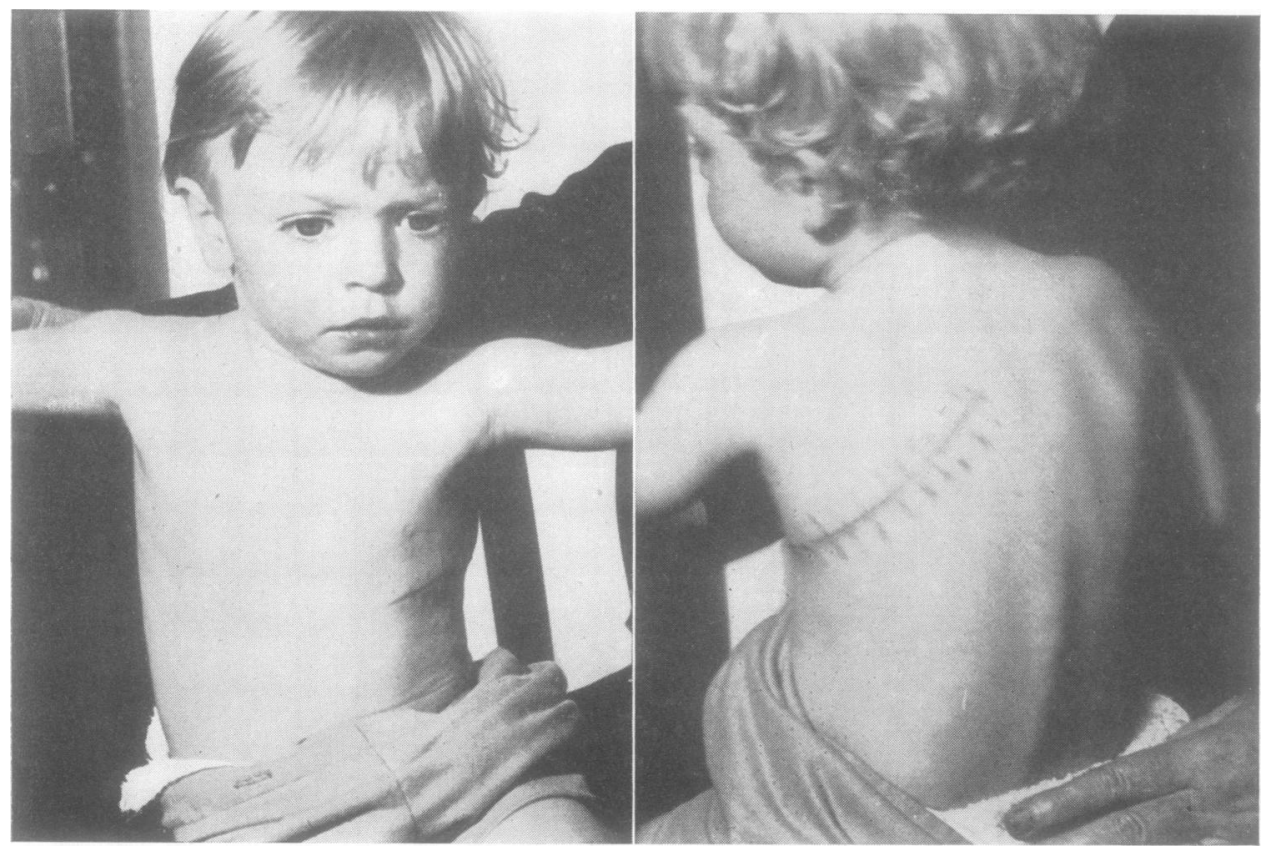

Figs. $4 a$ and $4 b$.-Fig. $4 a$ shows slight flattening of the left chest, and in Fig. $4 b$ that there is no asymmetry. 
The heart sounds were normal and to be heard laterally and posteriorly in the right lower chest. The vital capacity was $800 \mathrm{c.cm}$.

Blood analysis gave: Hb, $120 \%$; E.S.R., 5 mm.; R.B.C., 5,970,000 ; W.B.C., 8,000.

The Wassermann and Mantoux tests were negative.

Antero-posterior and left lateral radiographs of the chest (Figs. 6 and 7) showed deviation of the mediastinum to the right. The right hemithorax appeared smaller than the left and the intercostal spaces were narrower. The heart shadow was displaced backwards and to the right, obscuring the costophrenic angle. There was herniation of the left lung into the right hemithorax anteriorly. The gastric air bubble was visible under the left diaphragm. A barium swallow demonstrated deviation of the oesophagus to the right throughout its whole length (Fig. 8). At bronchoscopy the trachea was seen deviated to the right, the carina appeared normal, but the right main bronchus was small and tapered to a pin-point hole $1 \mathrm{in}$. from the bifurcation. Lipiodol $(3 \mathrm{ml}$.) was instilled into the right bronchus, and the antero-posterior and right lateral bronchograms showed the size and position of the rudimentary right lung (Figs. 9 and 10). An angiocardiogram was performed under general anaesthesia. Diodone $(20 \mathrm{ml} .70 \%)$ was injected into the basilic vein in the right upper arm, and six films were taken within 12 seconds (Figs. 11a, b, and $c$ ). The large left pulmonary artery and veins were demonstrated. The angiocardiograms gave the further information that the foramen ovale was closed and also the ductus arteriosus. In the last angiocardiogram the two normal kidneys were visible.

The child was discharged home.

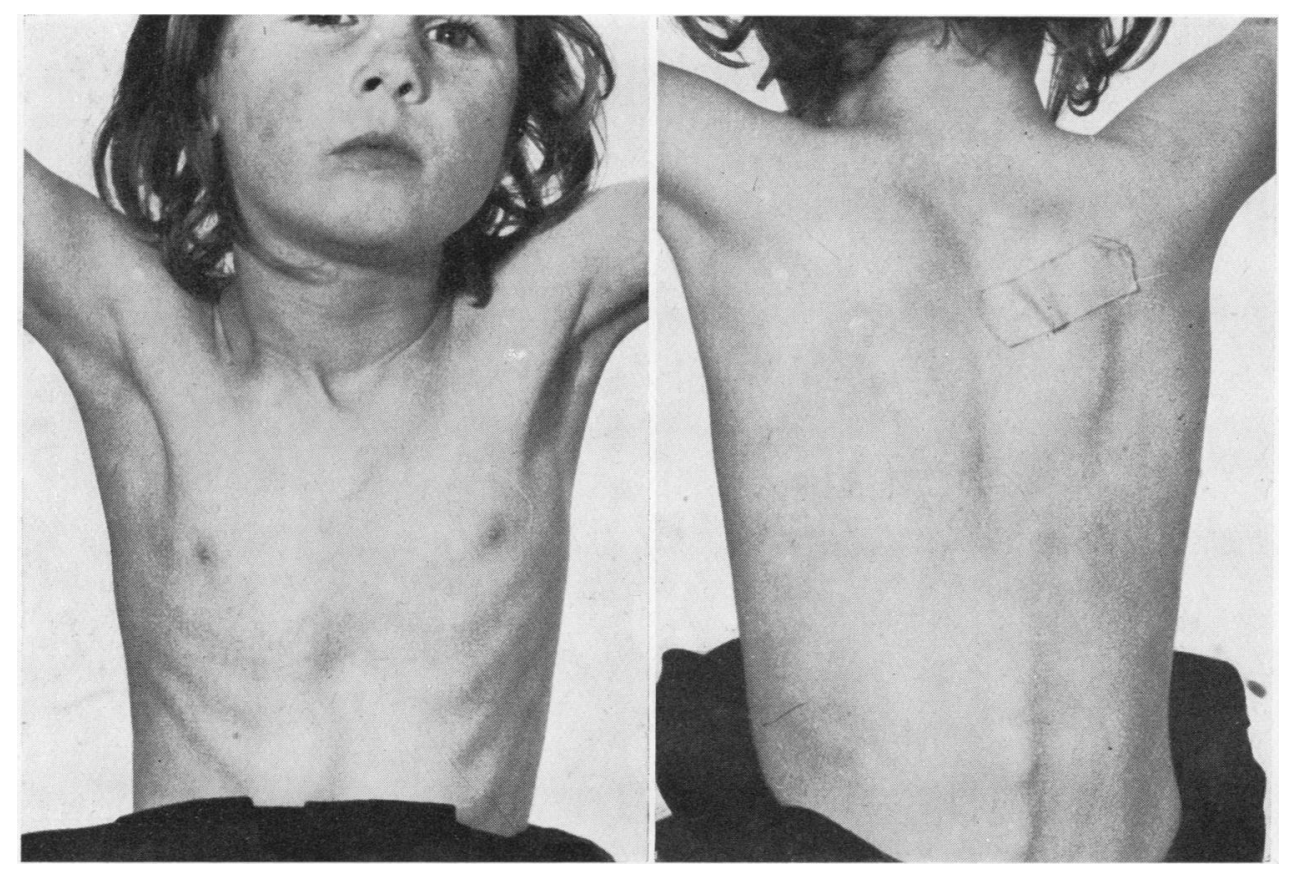

Figs. $5 a$ and $5 b$.-Fig. $5 a$ shows slight flattening of the right chest, and Fig. $5 b$ demonstrates that there is no asymmetry. 

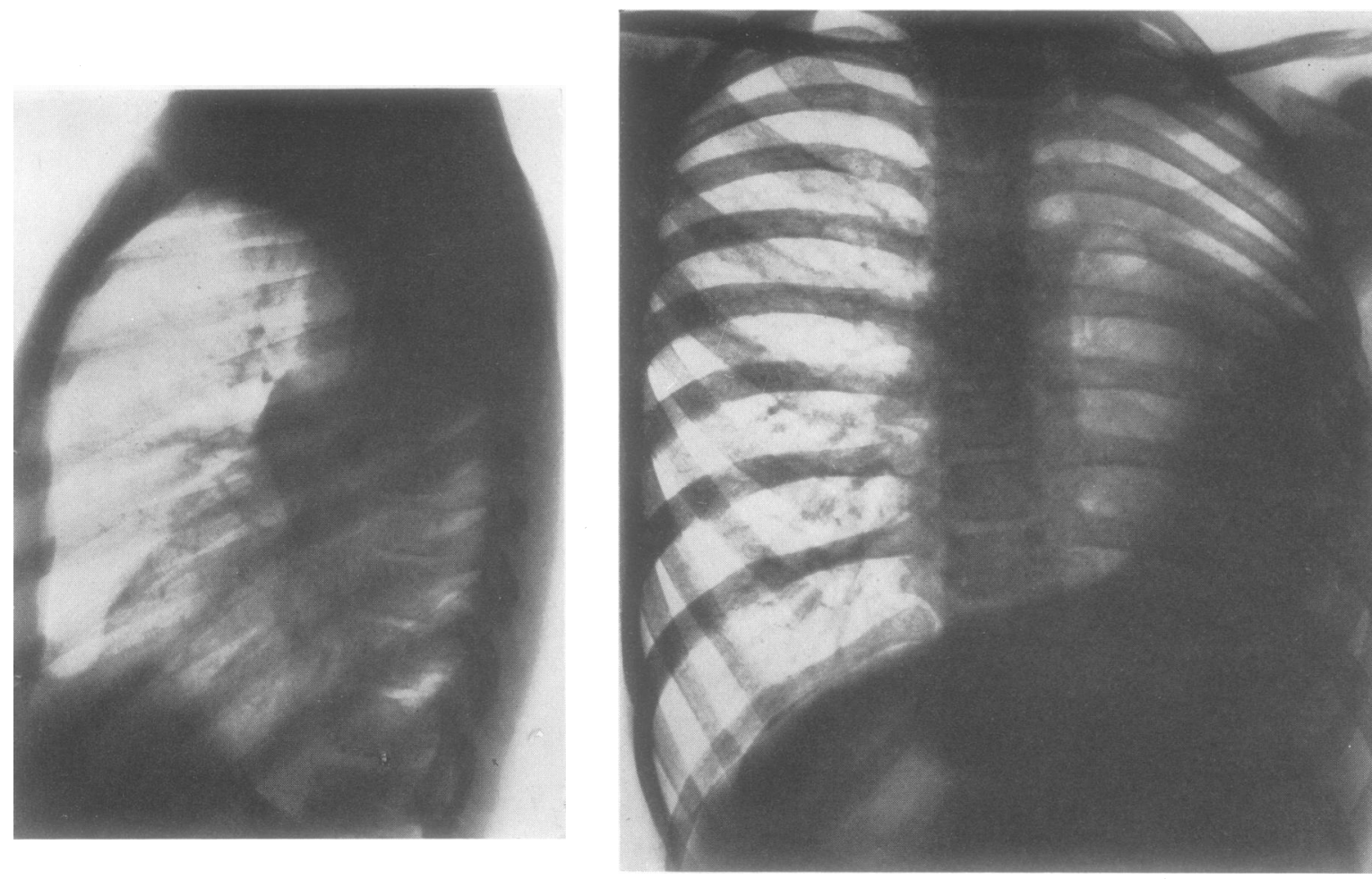

Fig. 7.

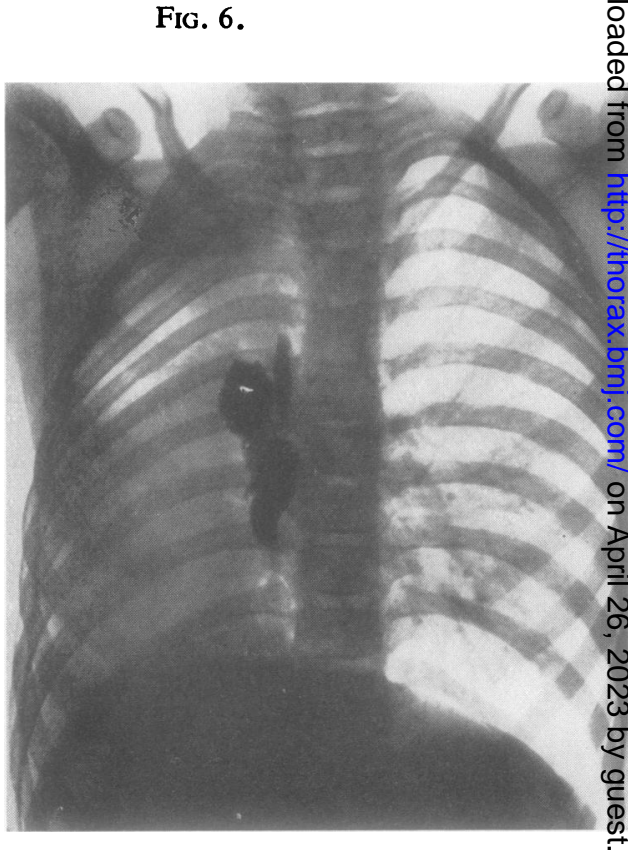

FIG. 8.

Fig. 9.

FIG. 7.-The anterior herniation of the left lung is demonstrated and also the backward displacement of the heart.

FIG. 6.-The heart shadow is seen in the right middle and lower zones laterally and the aorta arches back towards the middle line. The left lung occupies the greater part of the thorax.

Fig. 8. -The barium swallow demonstrates the mediastinal displacement to the right.

FIG. 9.-Bronchogram showing the narrow tapering right bronchus and filling of the rudimentary right lung. 
Fig. 10.-Bronchogram in the lateral view to show the extreme posterior position of the rudimentary right lung.

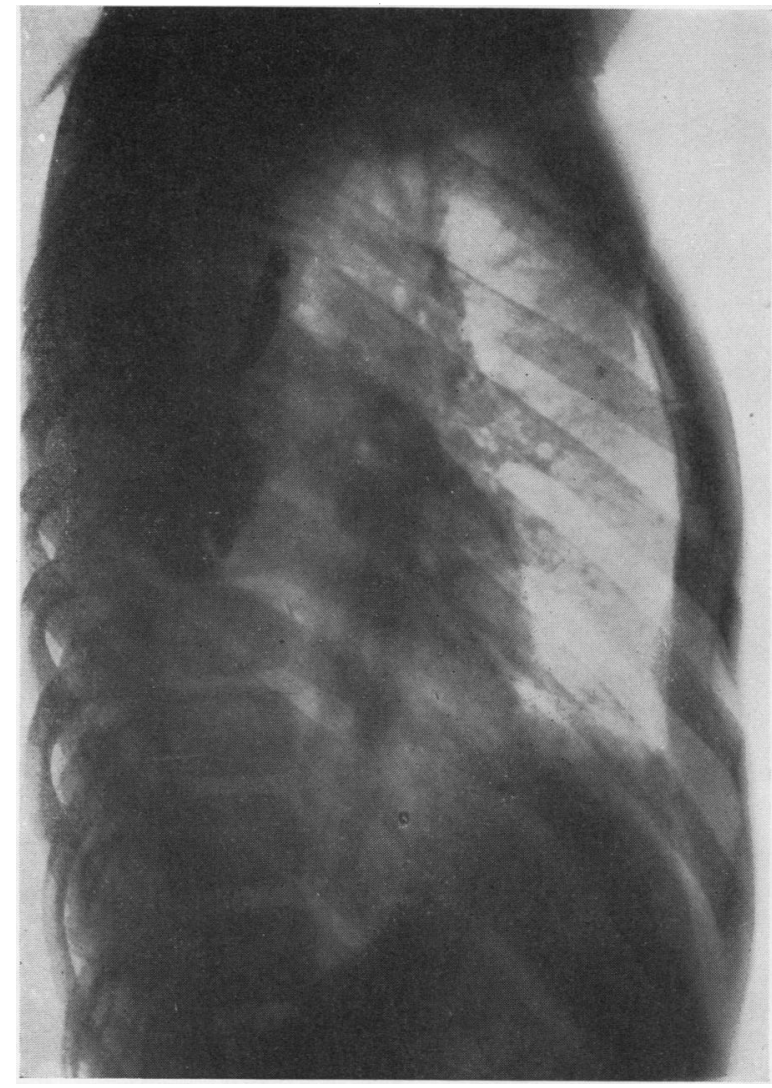

FIG. 10:

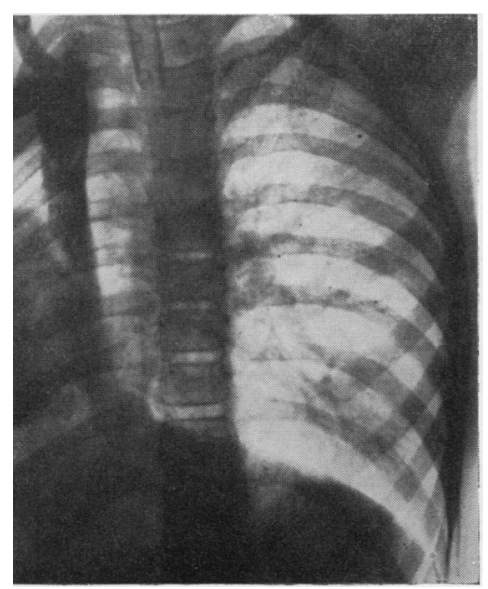

FIG. 11a.

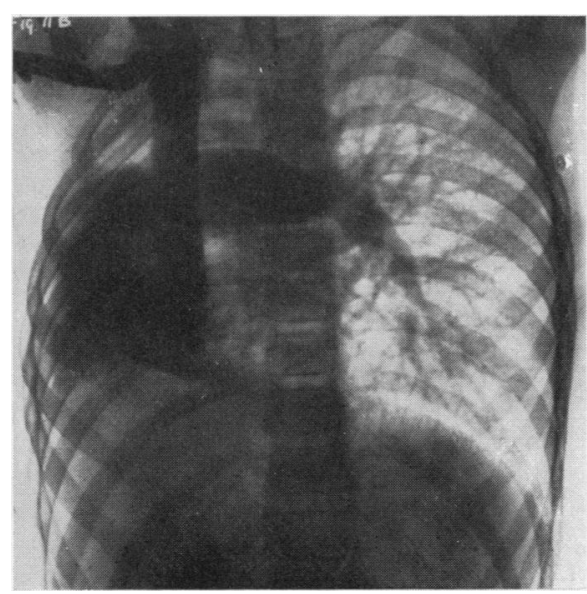

Fig. $11 b$.
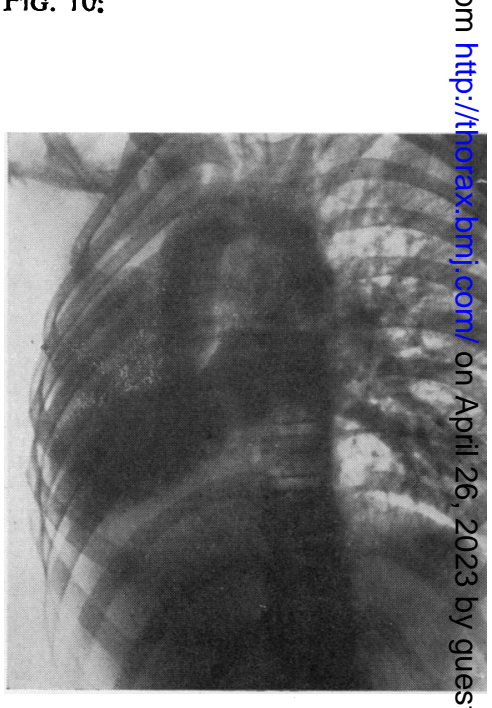

FIG. 11c.

FIG. 11b.-Angiocardiogram showing after two seconds the large left pulmonary artery traversing the middle line.

FIG. 11c.-Angiocardiogram after six seconds demonstrating the large left pulmonary vein, the left heart, and the aorta arching from right to left. 


\section{Discussion}

Schneider (1912) divided cases of agenesis of the lung into three groups, depending upon the degree of the defect, and I have followed this classification. (1) True aplasia ; that is, cases in which there is no trace of a lung, bronchus, or vascular supply to the affected side. (2) Cases in which there is a tiny out-pocketing of the trachea ; that is, a primordial bronchial bud, but no lung tissue. (3) Bronchus of small calibre, which ends in a fleshy structure without lobes and lies within the mediastinum.

The 87 collected cases fall into the groups as shown in Table II, but 18 cases could not be placed in any group through lack of information.

TABLE II

\begin{tabular}{|c|c|c|c|c|}
\hline Schneider's Types & $\begin{array}{c}\text { Other } \\
\text { Malformations }\end{array}$ & Absent Lung & Sex & $\begin{array}{l}\text { Time of } \\
\text { Diagnosis }\end{array}$ \\
\hline $\begin{array}{lll}\text { Group I } & \ldots & 30\end{array}$ & Other defects 37 & $\begin{array}{ccc}\text { Absent } & \text { left } & \\
\text { lung } & . & 48\end{array}$ & $\begin{array}{lll}\text { Male } & . & 38 \\
\end{array}$ & $\begin{array}{l}\text { Diagnosed dur- } \\
\text { ing life } \quad . .28\end{array}$ \\
\hline $\begin{array}{lll}\text { Group II } & \ldots & 32\end{array}$ & $\begin{array}{lll}\text { No other de- } & \\
\text { fects } & \ldots & 28\end{array}$ & $\begin{array}{ccc}\begin{array}{c}\text { Absent } \\
\text { lung }\end{array} & \text { right } & \\
& . & 35\end{array}$ & Female $\quad 36$ & $\begin{array}{l}\text { Diagnosed } \\
\text { post mortem } 59\end{array}$ \\
\hline $\begin{array}{lll}\text { Group III } & \ldots & 7\end{array}$ & Not given $\ldots \quad 22$ & $\begin{array}{ccc}\text { Absent } & \text { both } & \\
\text { lungs } & \ldots & 3\end{array}$ & Not given 13 & \\
\hline Not grouped. . 18 & & $\begin{array}{lll}\text { Not given } \ldots & 1\end{array}$ & & \\
\hline $\begin{array}{lll}\text { Total } & \ldots & 87\end{array}$ & Total & $\begin{array}{lll}\text { Total } & \ldots & 87\end{array}$ & $\begin{array}{ll}\text { Total } & 87\end{array}$ & Total \\
\hline
\end{tabular}

In many patients who had agenesis of the lung other malformations have been present, and lead one to believe that the condition is a true malformation and probably the result of an inherent defect in the germ plasm (Ferguson and Neuhauser, 1944). Nearly $50 \%$ have other defects: their distribution and nature can be seen in Table II : in seven cases patent ductus arteriosus, in five patent foramen ovale, and in three atresia ani were present. Other malformations were atresia oesophagi, short bowel, atresia uro-genitalis, exencephaly, horseshoe kidney, ventricular defect, hypoplasia of the face, hare lip and cleft palate, absence of the left diaphragm, absent left hand, absent right radius, bifid uvula, spina bifida, wedge-shaped vertebrae, hemivertebra, deformed ribs (with fusion of the third to the sixth right ribs), accessory thumb, closed foramen epiploica, rudimentary atlas, deformed external ear, congenital ptosis of both eyelids, small left scapula, and pulmonary veins entering the azygos vein.

Anomalies of the pulmonary vessels to the affected side were found in all cases where they were looked for ; they varied from complete absence of the pulmonary vessels to abnormalities in size and numbers, and abnormal relations to the heart or great vessels.

Agenesis occurs more often on the left side (Table II), but there seems to be no great difference in the numbers of left and right lungs missing. The distribution among men and women is also shown in Table II. 
Almost $50 \%$ of the patients died in the first five years of life, and of these 10 were stillbirths or lived only for a few hours. On the other hand it does not seem that only one lung is incompatible with reaching old age, and a patient with one lung has been reported by Heerup (1927) to have lived to the age of 72 . In the last decade the ever-increasing number of patients who have been subjected to pneumonectomy shows that patients with one lung are able to live a normal life without restrictions. Of the 87 cases 28 have been diagnosed during life and of these two were found after exploratory thoracotomy (Valle and Graham, 1944). The first case diagnosed during life was that described by Münchmeyer in 1885, the next in 1927, and as many as 24 in the last 10 years. Thirteen cases diagnosed during life were verified by postmortem examination and 15 patients were alive and well when last heard of.

Agenesis by itself does not give rise to symptoms unless complicated by bronchopulmonary disease. Most of the cases reported give a history of distressed breathing, wheezing respiration, cough, and sometimes of cyanosis. Others seem to have lived a normal life without symptoms. Patients with one lung appear to be harder hit by ordinary respiratory infections, and pneumonia was found as the cause of death in the majority.

Clinical Findings.-Asymmetry of the chest with flattening of the affected side and lagging on inspiration may be present, but the shape and movements of the chest are generally normal. By jugular palpation the trachea is often found to be deviated towards the side of the missing lung. The heart and mediastinum are displaced to the defective side, producing dullness on percussion with absent breath sounds at the base of this side posteriorly, anteriorly, and laterally. If the right lung is missing, the heart apex beat will be found on the right side simulating dextrocardia. The heart also rotates and heart sounds can be heard on the posterior wall of the chest. Marked herniation of the remaining lung can give normal physical findings especially in the upper part of the affected side ; the hypertrophied lung is also likely to give normal physical findings over its own side of the chest.

Postero-anterior Radiograph.-The heart shadow will be found on the side of the missing lung and close to the lateral chest wall. Unless there is marked herniation of the other lung, no aerating lung will be visible on the affected side. Quite characteristic is the hypertrophied remaining lung protruding across the midline with its vascular markings noticeable on the radiograph, and through the aerating lung the vertebral column appears more defined than usual. Narrowing of the intercostal spaces and a raised diaphragm are often noted on the defective side.

Barium Swallow.-This will reveal displacement of the oesophagus towards the side of the absent lung (Fig. 2), and bronchoscopy shows that the trachea is often displaced, and malformations such as narrowing, supernumerary tracheal rings, and absent pars membranacia (trachealis muscle) have been reported. By bronchoscopy it should be possible to differentiate in most cases between Schneider's types 1, 2, or 3 .

Bronchogram.- Lipiodol will outline the trachea and the bronchial tree, and help in grouping the cases. It will show the bronchial distribution in the existing lung and the degree of herniation. It is valuable in the differential diagnosis.

An angiocardiogram gives information as to the position of the heart and the pulmonary vessels, and at the same time reveals congenital malformations in the 
heart and possibly the kidneys, as shown in Figs. 11a, $b$, and $c$. I have found no records of this method used in the diagnosis of agenesis in the literature.

The Differential Diagnosis.-Pulmonary agenesis is most likely to be overlooked in childhood. The condition which resembles it most closely is atelectasis in the newborn, and radiographs of the chest taken in the early stages of this condition are indistinguishable from agenesis. Serial films, taken at intervals of months, show gradual aeration of lung tissue as described by Field (1946). Case 3 is an example of this and was originally diagnosed as agenesis.

\section{Cases Suggestive of Agenesis}

Case 3.-The provisional diagnosis was atelectasis in a newborn girl; she was 10 months old when admitted.

There was a history of cough since birth ; bronchitis developed at 2 months. Stridor was first noticed at 4 months. The child did not thrive as well as her twin sister. There was no clubbing of the fingers. The physical examination gave dullness and diminished breath sounds and an inspiratory wheeze and rales at left base. A radiograph, taken at 5 months old (Fig. 12), showed collapse of the left lung with herniation of the right lung. Three ovoid shadows were seen to the left of the spine, which might be glands and the cause of the collapse. A radiograph of the chest taken at 10 months showed aeration of the left upper lung (Fig. 13) with collapse of the left lower lobe. Bronchoscopy revealed pus coming from the left lower lobe, and bronchograms showed bronchiectasis in this lobe (Fig. 14).

Bronchiectasis with atelectasis may give a similar picture to agenesis. It is usual to see cystic spaces on the affected side, but in some cases there may be a complete opacity. Bronchoscopy and bronchography will establish the diagnosis of bronchiectasis. Case 4 is illustrative.

Case 4.-A boy of 9 years periodically had had a cough and sputum since whoopingcough as a baby. On examination the child looked well; there was no fingerclubbing. There were diminished movements, impaired percussion note, and poor air-entry over the left lung. The radiograph of the chest (Fig. 15) was suggestive of bronchiectasis affecting the left middle zone. There was a spina bifida occulta of the seventh cervical and first dorsal vertebra. The Mantoux reaction was positive. Bronchoscopy revealed almost complete stenosis beginning half an inch down the left stem bronchus, and pus was seen oozing from a pin-point hole. Bronchograms (Figs. 16 and 17) showed a block in the left stem bronchus, and suggested agenesis. At a later bronchoscopy, a ureteric catheter was passed through the stenosis, and sodium iodide instilled; this time the bronchogram revealed gross bronchiectasis of the left lung (Fig. 18).

Stenosis of a main bronchus by benign or malignant tumour or a tuberculous stricture may produce a complete collapse of the lung with clinical and radiological findings similar to those in agenesis. A representative example is given in Case 5.

Case 5.-A man, 54 years old, came to hospital complaining of haemoptysis on and off for one year. He also had pain in the left chest, dyspnoea, and clubbing of the fingers. Fluoroscopy showed an immobile left diaphragm and the oesophagus deviated to the left. At bronchoscopy the left main bronchus was found to be blocked by neoplasm situated at the level of the upper lobe orifice. A biopsy from the tumour showed epidermoid carcinoma. In this case the radiographs of the chest (Fig. 19) were very similar to those of a case of agenesis. 


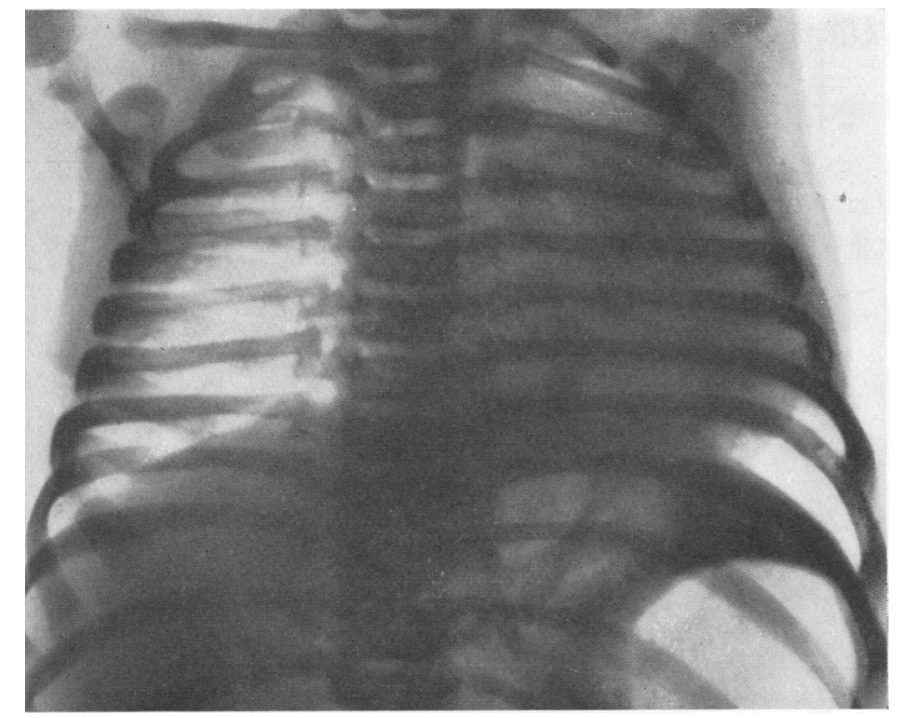

FIG. 12.-The heart shadow is well over to the left. The left lower lobe is collapsed and the aeration of the costophrenic sinus is due to the lingula.

FIG. 13.-Five months later showing upper loke more aerated and lower lobe collapsed.

FIG. 14.-Bronchogram showing normal left upper and collapsed left lower lobes.

FIG. 12.
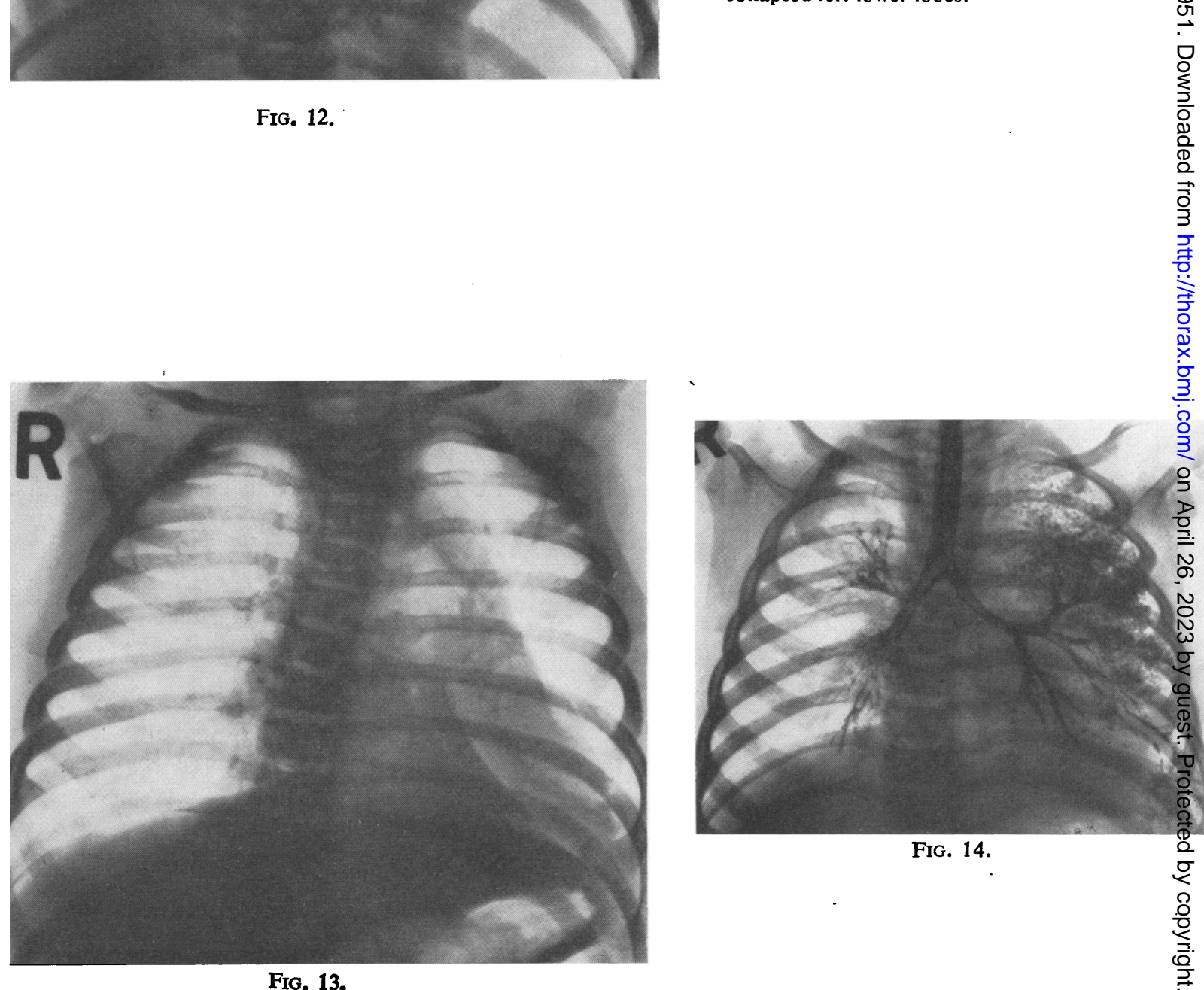


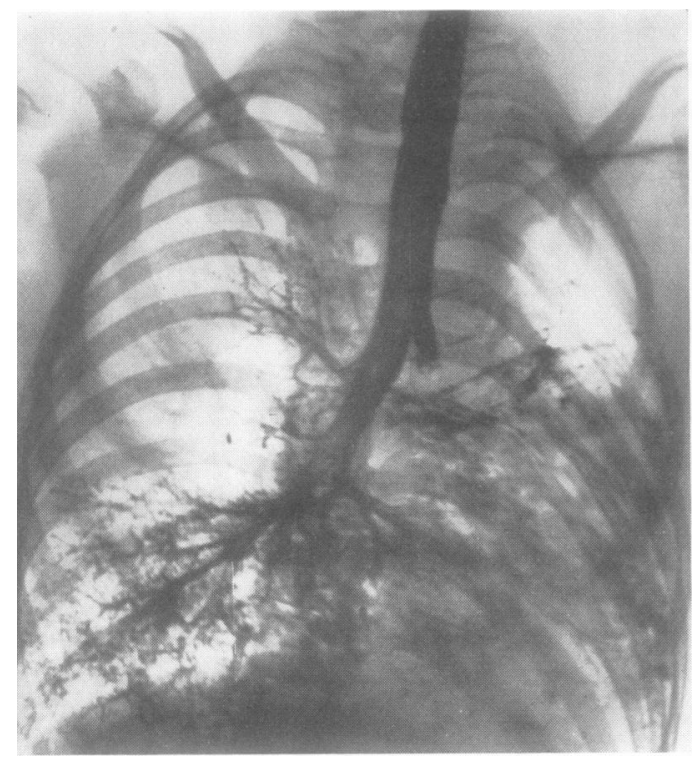

FIG. 16.

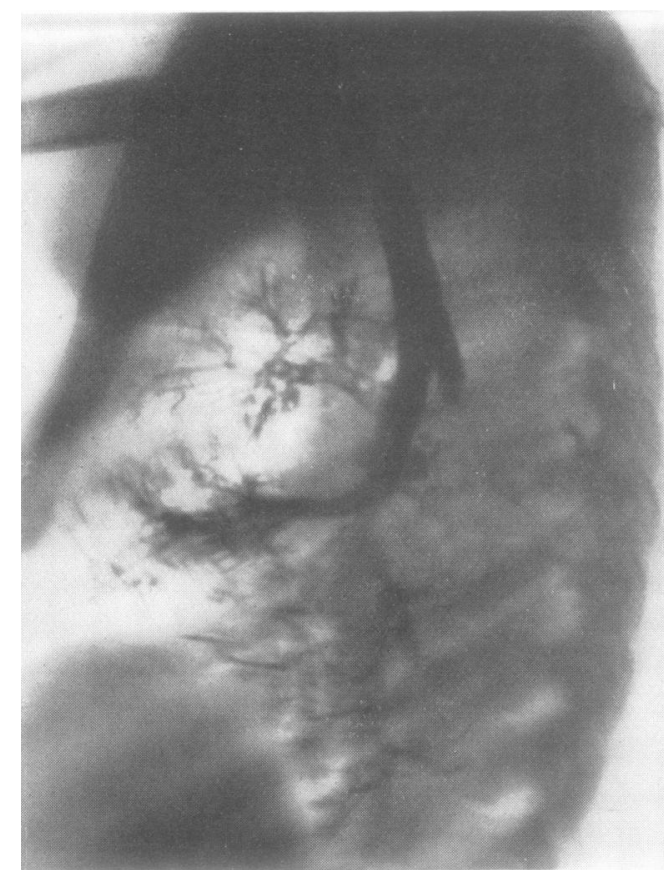

FIG. 17.

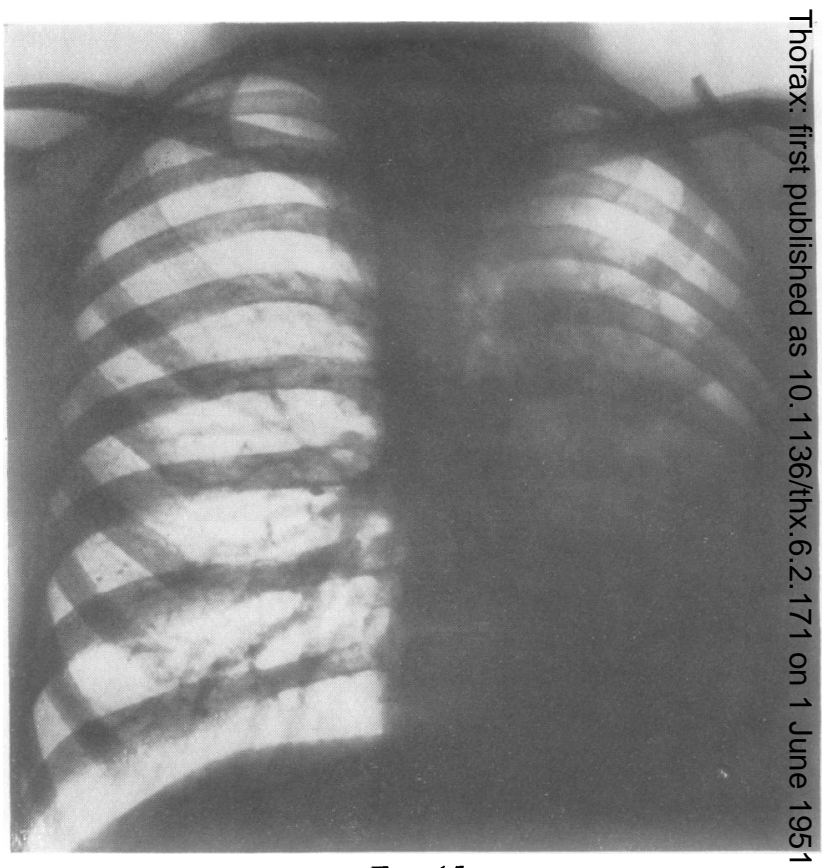

FIG 15

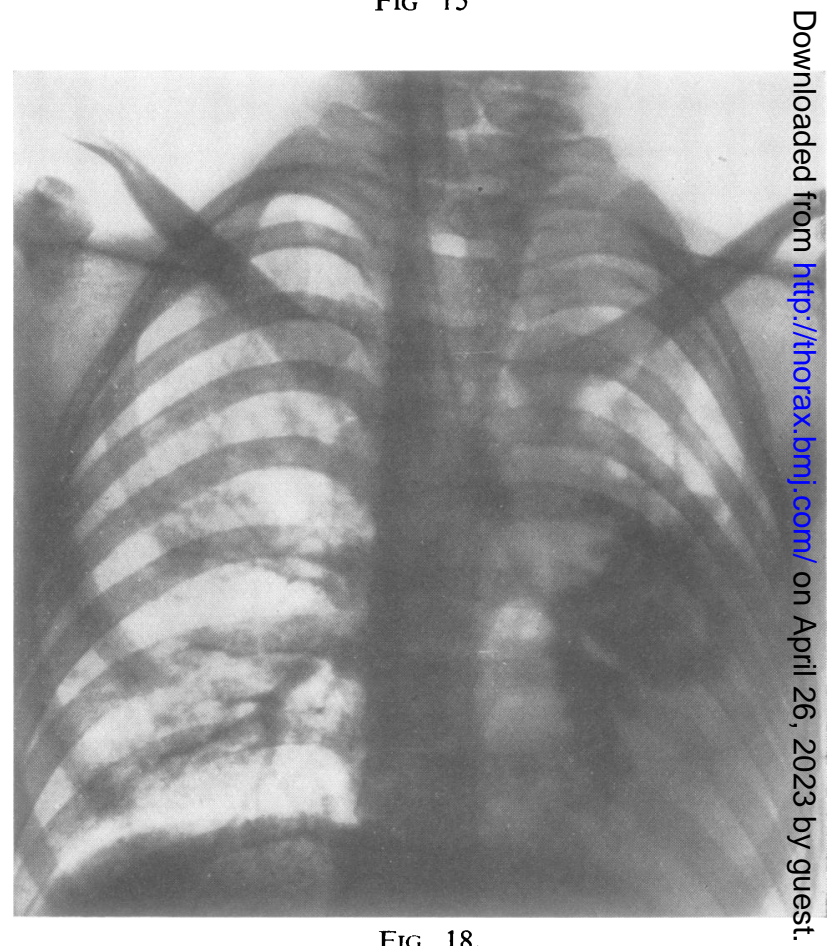

FIG. 18.

FIG. 15.-The right lung is large and herniates into the left 0 upper chest. The appearances in the left middle zone suggest the presence of bronchiectasis.

FIG. 16.-Bronchogram. Lipiodol was used and demonstrated the herniation of the right lung; $1 \mathrm{~cm}$. of the left bronchus is seen but no branches.

FIG. 17.-Bronchogram (lateral view).

FIG. 18.-Bronchogram after insertion of sodium iodide $\frac{0}{2}$ through a ureteric catheter showing gross bronchiectasis in the collapsed left lung. 


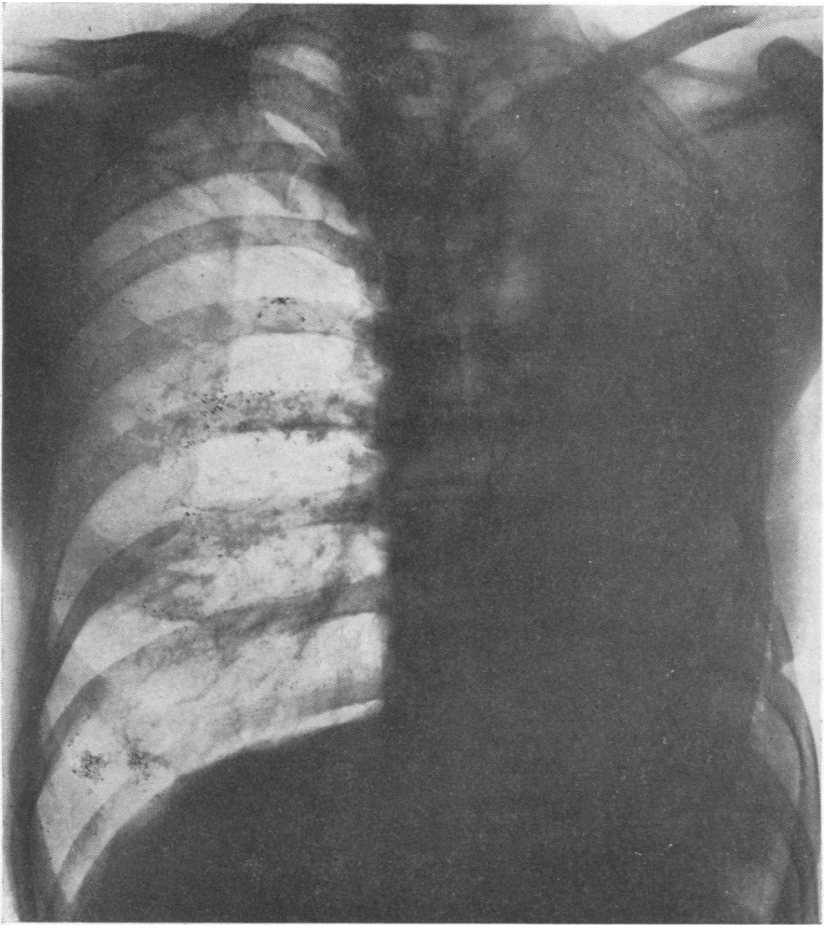

FIG. 19.

The appearances following pneumonectomy may be exactly similar, especially in children, and if studied should make one familiar with the picture of agenesis of the lung. In Case 6 pneumonectomy for bronchiectasis was performed without the removal of a rib.

Case 6.-A boy, 5 years old, had had German measles at 2 years old, and since then had been troubled by a productive cough. A bronchogram showed bronchiectasis of the whole left lung, and at the age of 5 a left pneumonectomy had been performed. The post-operative course was uncomplicated, and the child was seen four months later well and symptomiess.

Radiographs of the chest (Fig. 20) showed a picture identical with that of a true agenesis of the left lung. The bronchogram showed (Fig. 20a) the right bronchial tree and the herniation into the left chest.

Atelectasis of one lung caused by compression leaves the patient with only one functioning lung. Large dermoid cysts, pleural effusion, empyema, extrapulmonary intrathoracic tumours, spontarieous pneumothorax, haemothorax, large diaphragmatic hernia, and congenital giant cysts, or cysts developed in later life, can all be responsible for this condition. As a rule the atelectatic lung will expand as soon as the cause of compression has been removed, but if the lung is congenitally hypoplastic it may be impossible to inflate, as happened in the following case.

Case 7.-A woman aged 68 years had had no chest symptoms until September, 1949, when she developed a series of colds and coughs, together with increased shortness of breath and a tight feeling in the upper part of the left chest. On examination she was seen to be thin, dyspnoeic, but not cyanosed. The thorax was symmetrical with some inspiratory lagging of the left hemithorax. The physical findings were normal over the right chest. The left side was hyper-resonant and the breath sounds were absent. The vital capacity was $900 \mathrm{c.cm}$. Radiographs of the chest (Fig. 21) showed displacement of the mediastinum to the right, with absence of lung markings in the left hemithorax. At the level of the tenth left rib posteriorly a curved line suggestive of the margin of a giant cyst was visible. At bronchoscopy the trachea was seen to be markedly deviated to the right. The left bronchial tree was compressed, but no other abnormality was seen. A pneumothorax needle was inserted, and a communication between the air space and the bronchial tree was demonstrated. At thoracoscopy two large lung cysts were seen, and a later radiograph of the chest showed air between the wall of the cyst and the chest wall (Fig. 22). The day after the thoracoscopy a thoracotomy was performed. A large bilocular cyst, adherent to the diaphragm and partly to the chest wall and medially connected with a small collapsed left lung, was found. The cysts were stripped off the chest wall and the lung, leaving a small 
FIG. 20.-Appearances seen after left pneumonectomy. The right lung herniates into the upper left chest.
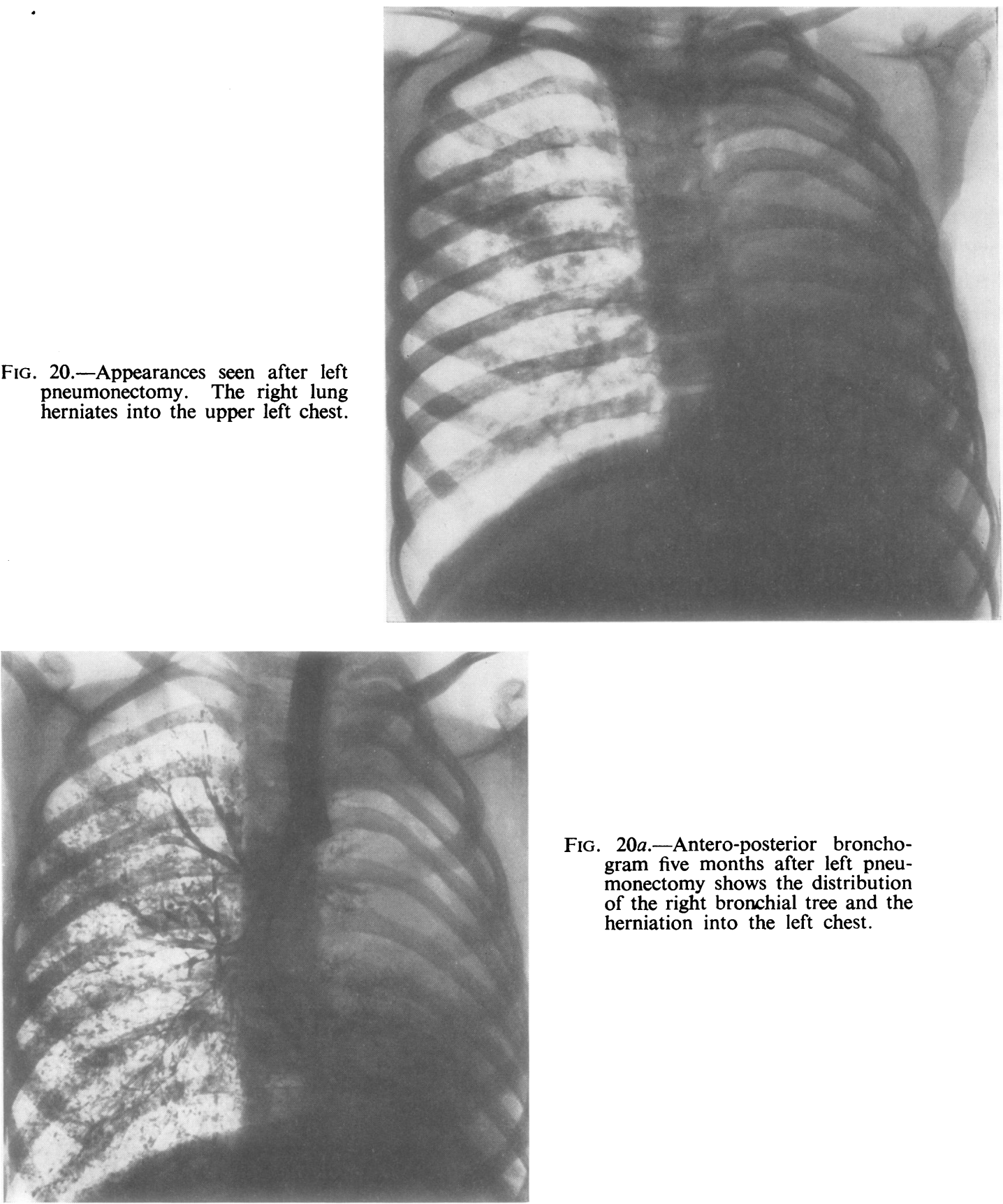

FIG. 20a.-Antero-posterior bronchogram five months after left pneumonectomy shows the distribution of the right bronchial tree and the herniation into the left chest.

fistula on the lingular segment. After removal of the cysts it proved impossible to re-expand the left lung, and it was decided to proceed with a pneumonectomy. A radiograph, taken three weeks after the pneumonectomy, showed less deviation of the mediastinum to the right (Fig. 23). The cysts and the hypoplastic lung are seen in Figs. $25 a$ and $b$. A bronchogram of the removed lung showed a collapsed lung with a normal distribution of the bronchial tree (Fig. 24). The post-operative course was uneventful, and the vital capacity three weeks after the operation was $850 \mathrm{c.cm}$. 


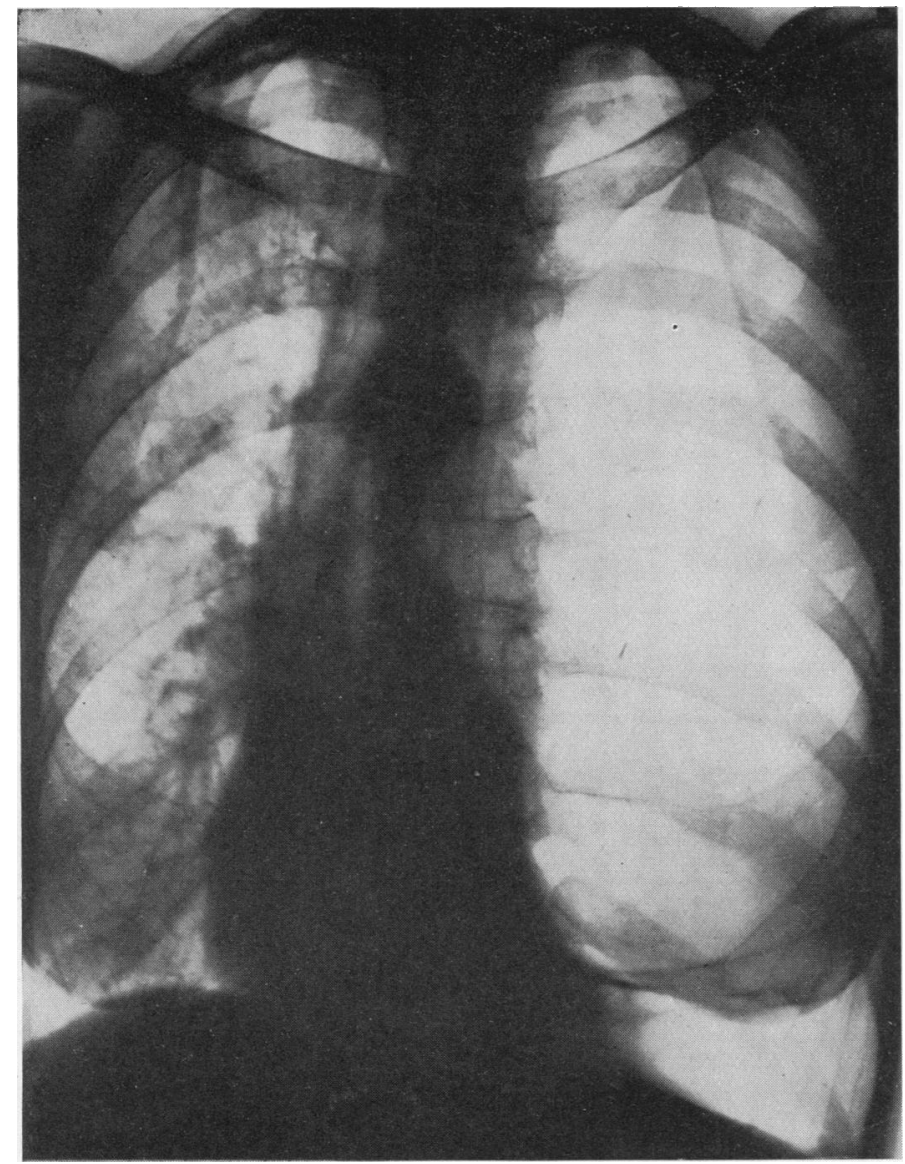

Fig. 21.-In the left lower chest the curved margin of a giant cyst iso seen. There are no normal lung markings. The mediastinum is displaced to the right.

FIG. 22.-After thoracoscopy showing the curvilinear shadows which $x$ indicate the crumpled cyst wall.

FIG. 24.-Bronchogram of the removed lung shows a collapsed lung with å normal distribution of the bronchial tree.

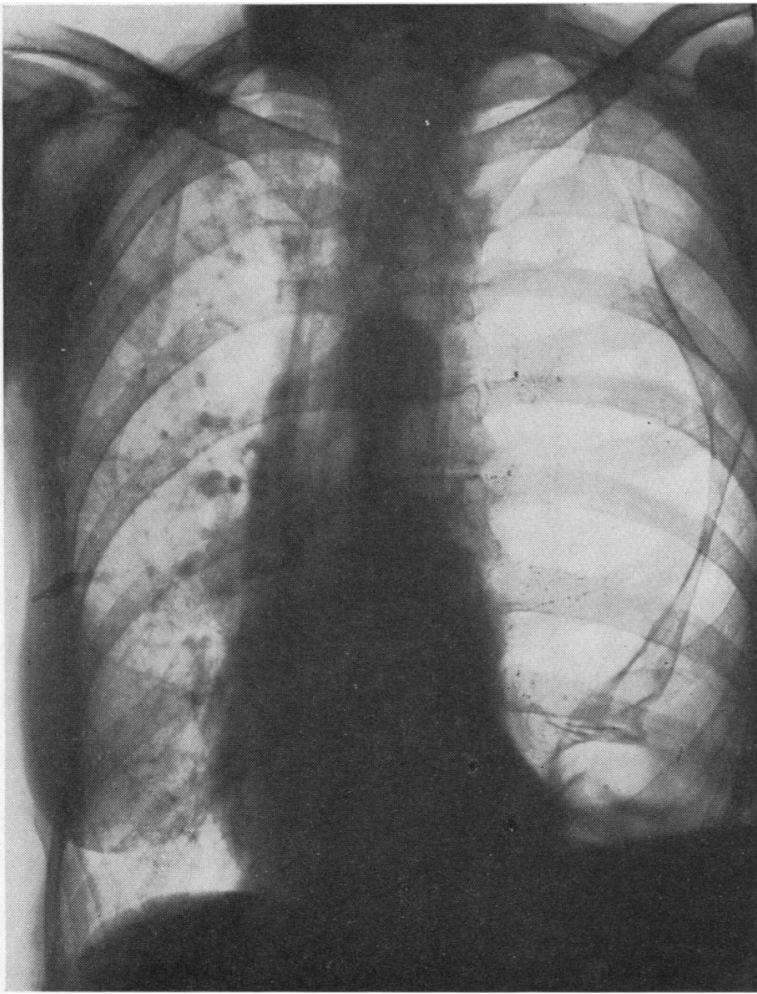

FIG. 22. 


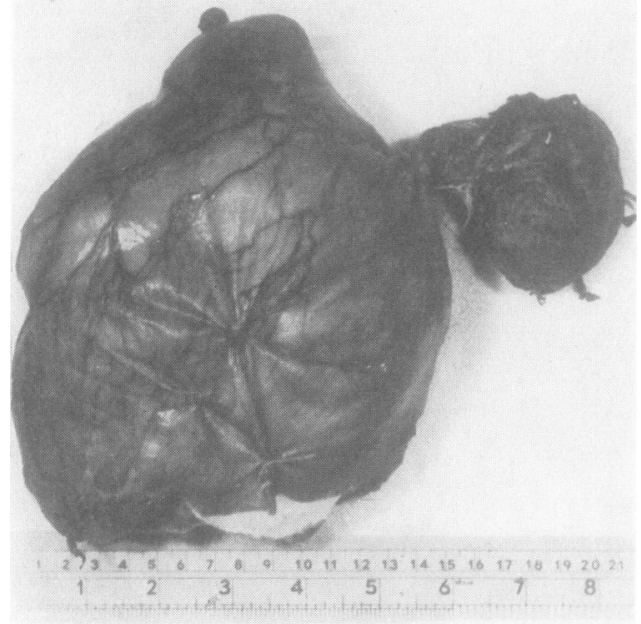

FIG. 25a.-The lung cyst.

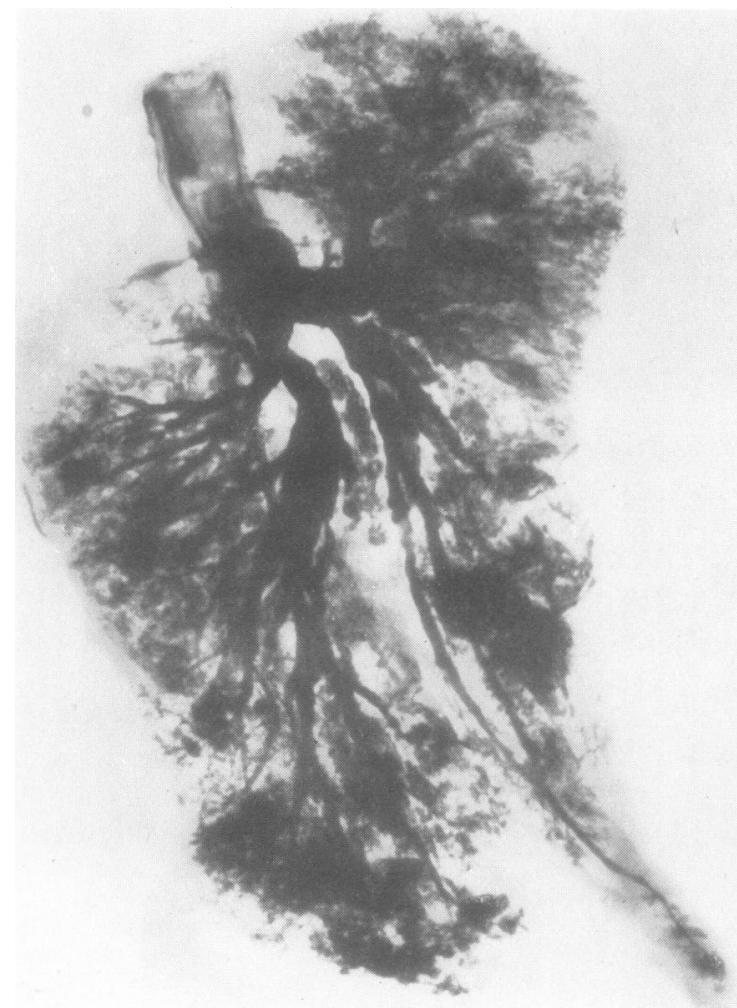

FIG. 24.

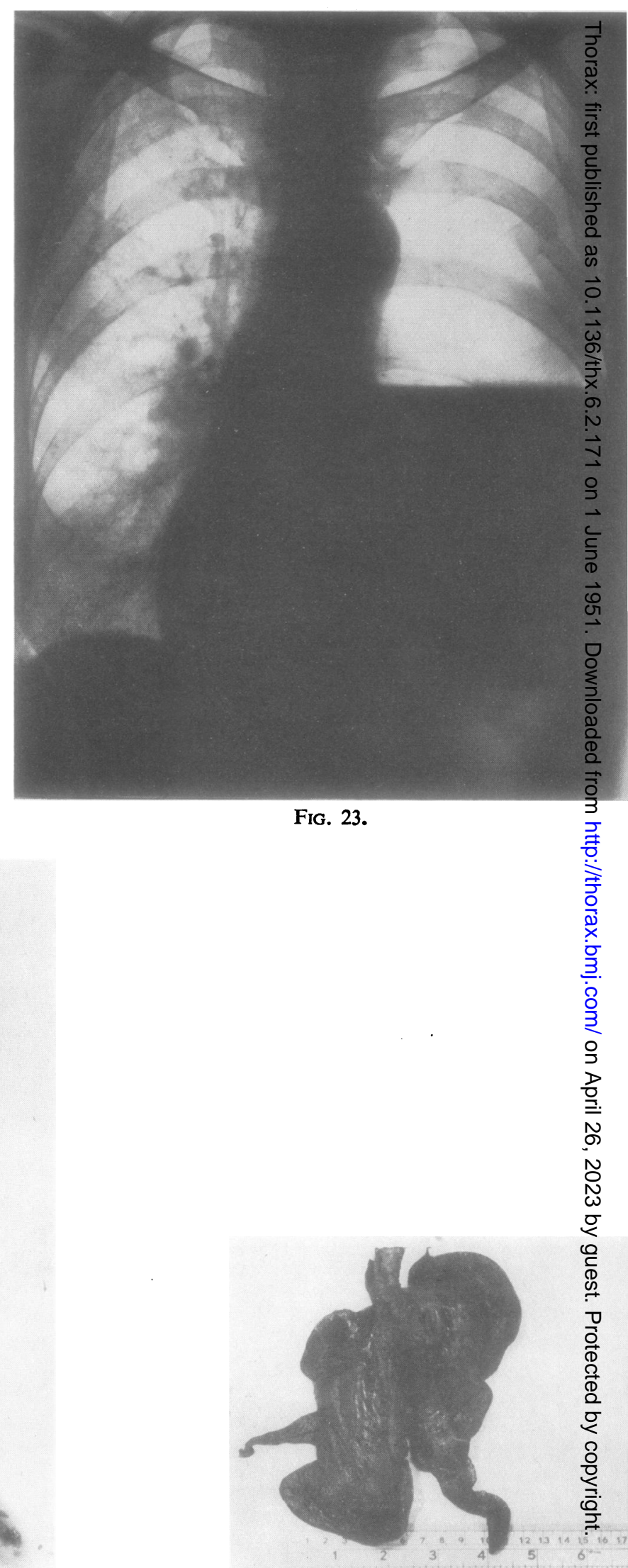

FIG. 25b.-The hypoplastic lung. 


\section{SUMMARY}

Two cases of pulmonary agenesis are recorded, and the clinical and radiological findings in this condition are described.

The principal findings in 85 cases collected from the literature are tabulated.

Some problems in differential diagnosis are discussed, and examples given of conditions which might be confused with agenesis.

My thanks are due to Mr. George A. Mason, under whose care these cases were admitted, for having encouraged me to publish this paper, and to Dr. Whately Davidson for putting the radiographs and the interpretation of them at my disposal.

\section{REFERENCES}

Allen and Affelbach (1925). Surg. Gynec. Obstet., 41, 375.

Bohnholtzer, E. (1938). Beitr. path. Anat., 101, 614.

Bönniger, M. (1928). Med. Klin., 24, 258. (1931). Ibid., 27, 1568.

Bowden, K. M. (1947). Med. J. Aust., 1, 646.

Burger, R. A. (1947). Amer. J. Dis. Child., 73, 481.

Choisser, R. M., and Bloedron, W. A. (1939). New Int. Clin., n.s. 2, 2, 243.

Deweese, E. R., and Howard, J. C. (1944). Radiology, 42, 389.

Ellis, A. G. (1917). Amer. J. med. Sci., 154, 33.

Ferguson, C. F., and Neuhauser, E. (1944). Amer. J. Roentgenol., 52, 459.

Field, E. C. (1946). Arch. Dis. Childh., 21, 61.

Garber, R. L. (1945). Amer. J. Roentgenol., 53, 129.

Gartside, V. O. B. (1943). Brit. J. Radiol., 16, 69.

Goehle, O. L. (1920). Amer. J. med. Sci., 159, 237.

Heerup, L. (1927). Hospitalstidende, 70, 1165.

Hurwitz, S., and Stephens, H. B. (1937). Amer. J. med. Sci., 193, 81.

Jamuni, A., and Ellis, A. G. (1938). Ibid., 196, 824.

Killingsworth, W. P., and Hibbs, W. G. (1939). Amer. J. Dis. Child., 58, 571.

Levy, C. S. (1920). Amer. J. med. Sci., 159, 237.

Lochow (1929). Zbl. allg. Path. path. Anat., 46, 170.

Madigan, D. G. (1941). Tubercle, Lond., $22,144$.

Mitchell, H. E. (1946). Ann. Otol., etc., St. Louis, 55, 609.

Mollison

Münchmeyer (1885). Cited by Welsch, K. (1928). Frankfurt. Z. Path., 36, 192.

Nesbit, W. M., Paul, K. W., and Middleton, W. S. (1947). Amer. J. Roentgenol., 57, 446.

Oberwarth (1904). Cited by Bohnholtzer, E. (1938). Beitr. path. Anat., 101, 614.

Olcott, C. T., and Dooley, S. W. (1943). Amer. J. Dis. Child., 65, 776.

Pierson, W. M. (1946). Ann. Otol., etc., St. Louis, 55, 604.

Pozze. Cited by Meckel, J. F. (1812). Handbuch der Pathologischen Anatomie, vol. 1. Leipzig.

Rienhoff, W. F. (1937). J. thorac. Surg., 6, 254.

Riviere (1779). Cited by Bohnholtzer, E. (1938). Beitr. path. Anat., 101, 614.

Schneider, P. (1912). In Schwalbe, E., Die Marphologie der Missbildungen des Menschen und der Tiere, vol. 3. Jena.

Selander

Schmit, H. (1893). Virchows Arch., 134, 25.

Sömmering. Cited by Meckel, J. F. (1812). Handbuch der Pathologischen Anatomie, vol. 1. Leipzig.

Stokes, H. L., and Brown, C. J. (1940). Med. J. Aust., 1, 49.

Valle,.A. R., and Graham, E. A. (1944). J. thorac. Surg., 13, 345.

Van Loon, E. L., and Diamond, S. (1941). Amer. J. Dis. Child., 62, 584.

Von Eicken (1927). Med. Klin., 23, 1836.

Wasmuth, K. (1938). Frankfurt. Z. Path., 52,519

Wehr and Clemens (1934). Cited by Bohnholtzer, E. (1938). Beitr. path. Anat., 101, 614

Wollmann (1891). Ibid.

Yampolsky, J., and Fowler, C. D. (1938). Arch. Pediat., 55, 293. 